\title{
Motivation Effect on the Performance of Employee Relations and Protocol the Secretariat of City Banjarbaru
}

\author{
Adeyasya Aziza*, Budi Suryadi, Jamaluddin
}

Master Program of Government Science, Lambung Mangkurat University, Banjarmasin, Indonesia

DOI: $\underline{10.36348 / \text { sijlcj.2019.v02i11.006 }}$

| Received: 08.11.2019 | Accepted: 15.11.2019 | Published: 19.11.2019

*Corresponding author: Adeyasya Aziza

\section{Abstract}

This study aims to determine how many effects of Motivation on Employee Performance of Public Relations and Protocol Regional Secretariat Banjarbaru, a method used in this research is quantitative method, with a population of 25 samples of 25 people and data analysis techniques with the research instrument validity, reliability, classical assumptions and using multiple linear regression. The results showed that the variables of Intrinsic Motivation Extrinsic motivation and partially significant effect on employee performance of Public Relations and Protocol Banjarbaru City Secretariat,

Keywords: Motivation Extrinsic and Intrinsic Motivation and Performance Officer.

Copyright @ 2019: This is an open-access article distributed under the terms of the Creative Commons Attribution license which permits unrestricted use, distribution, and reproduction in any medium for non-commercial use (NonCommercial, or CC-BY-NC) provided the original author and source are credited.

\section{INTRODUCTION}

Performance comes from a term called the actual job performance means performance. Factors that could affect the performance of that employee motivation is the driving force, someone, to do something to someone or yourself take the desired action [1]. The emergence of motivation against a person driven by the existence of a necessity of life whether it is secondary and primary needs. If the requirements are met, then the person's accomplishments and performance can be increased following the objectives of the organization [2]. An organization should motivate employees. The most important factor in determining the success and survival of the organization is the performance of employees.

Research Iriani previous research [3] with the title of Intrinsic Motivation, Extrinsic Motivation and Work Discipline Effect on Employee Performance in Sambas District Education Office who found the research. The results showed evidence from the results (f) simultaneous test that shows negotiate (38.773) with significant points $(0,000)$, which is much smaller than alpha of 0.05 . Along with the results (t), partial showed a significant point of the three independent variables, respectively for $0,000,0,009$ and 0,000 which is much smaller than alpha of 0.05 . The assumption is received from the two texts is Ho is rejected,

A similar study conducted Maulana .2015 entitled "Effect of Intrinsic Motivation, Extrinsic
Motivation, and Organizational Commitment on Employee Performance at Bank BTN Branch Malang". The results of the analysis of intrinsic motivation, extrinsic motivation and work experience as independent variables significantly influence employee performance as the dependent variable. where significant influence intrinsic motivation because of the significance level of 0.47 which is less than 0.05 . Extrinsic motivation significant influence because of the significance of 0.000 which is less than 0.05 , and then to work experience also affects the performance of the employee because of the significance level of 0.021 less than 0.05 . The equation of this previous research with this study is to use the same variables that Intrinsic Motivation and Extrinsic Motivation with the Herzberg method and the variable performance and using multiple linear regression analysis. The difference is not using organizational commitment variables, population and sample number, time and object of research. This article aims to describe the Effect of Motivation on Employee Performance of Public Relations and Protocol Banjarbaru Regional Secretariat.

\section{RESEARCH METHODS}

A quantitative approach with survey method selected in the study. This approach is intended to formulate hypotheses to provide answers to the problem formulated in the sentence statement. Survey method where the data obtained from questionnaires is the perception of respondents in analyzing which then formulated into functional relationships. Quantitative 
research is presented in some data sources. This study is a quantitative intending to explain the causal relationship between variables through hypothesis testing. This study is included in the Explanatory types are the type of research that aims to identify the potential correlation between one variable with other variables or how a variable affects other variables [3, 4].

The study examined the effect is causal because between variables. This approach starts from the formulation of the problem and then withdrawn a hypothesis, as well as the next theory, is to create a model analysis, Identifying variables, operational definitions, data collection (primary data or data secondary) [5]. Based on the population and samples, And then perform the analysis. Location research taken is the Public Relations and Protocol Setdako Banjarbaru, Jalan Panglima Batur No. 1 Banjarbaru District of North Banjarbaru Banjarbaru South Kalimantan province. This is because of the workload of employees of public relations and protocol that is considered more than most other employees.

There is a population of 25 (twenty-five) that constitute whole Executing on the Public Relations and Protocol Banjarbaru Setdako both civil servants and non-civil servants. The entire population as research object because it does not reach 100 people. The research variables described as follows: 1) The dependent variable (Y)employee performance, include; tupoksi understanding, innovation, speed of work, accuracy of work, cooperation, 2) Extrinsic motivation (X1), include; policy and administration, supervision, salary, interpersonal relations, working conditions, 3) Intrinsic Motivation (X2), include; success, recognition/awards,responsible, Employment, development. Activities include data collection techniques; literature study, observation, and questionnaire distribution. Mechanical scoring on a Likert Scale questionnaire used to see the attitude, perception, and opinion of a person/group of social phenomenon [6].

The validity test used is the analysis item. Analysis item is a correlation score of each item with the total score is the sum of each score point. If there are items that can not qualify, then it added the item can not be investigated. Requirements that must be met is a must-have criterion, namely:

a. If $r \geq 0.30$, then the items of the questionnaire is a valid question

b. If $\mathrm{r} \leq 0.30$, then the items the question of the questionnaire is not valid.
Test the validity of this research using Product Moment Correlation:

$$
r=\frac{n \cdot \sum X Y-\sum X \cdot \sum Y}{\sqrt{n \cdot \sum X^{2}-\left(\sum X\right)} \text { 2. } \sqrt{n \cdot \sum Y^{2}-\left(\sum Y\right)^{2}}}
$$

Reliability test used instrument uses reliability analysis study with Cronbach alpha technique which has the following formula:

$$
\alpha=\left[\frac{n}{n-1}\right]\left[\frac{S^{2}-\sum_{i=2}^{n} S i^{2}}{S^{2}}\right]
$$

The data analysis technique quantitative analysis using multiple linear regression model (multiple linear regression method). The formulation of the mathematical form of multiple linear regression analysis will be used to know the influence of the independent variables or is Motivationextrinsic and Intrinsic Motivation to the dependent variable (dependent) that employee performance is as follows:

$$
\mathrm{Y}=\mathrm{a}+\mathrm{b} 1+\mathrm{b} 2 \mathrm{X} 2+\mathrm{X} 1 \mathrm{e}
$$

Estimation techniques bound or dependent variable is the basis of regression analysis using the SPSS statistical calculation assistance program (Statistical Product and Service Solution) version 21 for Windows. Simultaneous Test is used to determine the influence jointly independent variable (free) to variable dependent (attached). To be known whether significant or not, it is used the probability of 5\% $(\alpha=0.05)$ [7]. AsTest forms Partial final test used to determine the independent variable (independent) individually significant influence on the dependent variable (dependent). Of meaningful variables, then the selected variables dominant. To determine the influence of each independent variable and the most decisive (dominant) influence on the dependent variable of a linear regression model then is used coefficient Beta (Beta Coefficient) of each variable standardized (standardized coefficient) $[7,8]$.

\section{RESULTS AND DISCUSSION}

Data collected in the study conducted by distributing questionnaires to the Public Relations and Protocol Regional Secretariat Banjarbaru as respondents. The number of questionnaires was distributed by 25 (twenty-five) questionnaire. Analysis of the data obtained from the results of the questionnaire respondents is important to know the characteristics of respondents sampled in this study. Characteristics of respondents include Gender, Age, Status and Occupation, seen in the table below: 


\section{Profile of Respondents Research}

Gender

Table-1: Characteristics of Respondents by Gender

\begin{tabular}{|c|c|c|c|}
\hline No. & \multicolumn{1}{|c|}{ Gender } & $\begin{array}{c}\text { Frequency } \\
\text { (person) }\end{array}$ & Percent (\%) \\
\hline 1 & Male & 11 & $44 \%$ \\
\hline 2 & woman & 14 & $56 \%$ \\
\hline \multicolumn{2}{r|}{ total Respondents } & $\mathbf{2 5}$ & $\mathbf{1 0 0 \%}$ \\
\hline
\end{tabular}

Source: Personal (data processing)

Table 1 provides information that the Public Relations and Protocol Banjarbaru Regional Secretariat of the respondents in this study were 11 people (44\%) Male - Male and 14 (56\%) were women.

Age

Table-2: Characteristics of Respondents by Age

\begin{tabular}{|c|l|c|c|}
\hline No. & \multicolumn{1}{|c|}{ Age } & Frequency (person) & Percent (\%) \\
\hline 1 & Under 20 years & 0 & $0 \%$ \\
\hline 2 & $20-30$ Years & 4 & $16 \%$ \\
\hline 3 & $31-40$ Years & 13 & $52 \%$ \\
\hline 4 & 40 Years and Over & 8 & $32 \%$ \\
\hline \multicolumn{2}{|c|}{ total Respondents } & $\mathbf{2 5}$ & $\mathbf{1 0 0}$ \\
\hline
\end{tabular}

Source: Personal (data processing)

Table 2 shows that the age of an employee of Public Relations and Protocol Banjarbaru Regional Secretariat of the respondents in the study were as many as four people (16\%) were aged 20-30 years, 13 patients (52\%) were aged $31-40$ years and as many as 8 people (32\%) were aged 40 years or older.

\section{Status}

Table-3: Characteristics of Respondents by Status

\begin{tabular}{|c|l|c|c|}
\hline No. & \multicolumn{1}{|c|}{ Last education } & $\begin{array}{c}\text { Frequency } \\
\text { (person) }\end{array}$ & Percent (\%) \\
\hline 1 & Marry & 18 & $72 \%$ \\
\hline 2 & Single & 7 & $28 \%$ \\
\hline 3 & Widow widower & 0 & $0 \%$ \\
\hline & total Respondents & $\mathbf{2 5}$ & $\mathbf{1 0 0}$ \\
\hline
\end{tabular}

Source: Personal (data processing)

Table 3 shows that the educational level of Public Relations and Protocol Banjarbaru Regional
Secretariat of the respondents in this study were 18 people $(72 \%)$ are married, and $7(28 \%)$ are unmarried.

\section{Last education}

Table-4: Characteristics of Respondents by Education

\begin{tabular}{|c|l|c|c|}
\hline No. & \multicolumn{1}{|c|}{ Last education } & $\begin{array}{c}\text { Frequency } \\
\text { (person) }\end{array}$ & Percent (\%) \\
\hline 1 & SMA / equal & 6 & $24 \%$ \\
\hline 2 & Diploma & 8 & $32 \%$ \\
\hline 3 & Bachelor & 9 & $36 \%$ \\
\hline 4 & Postgraduate & 2 & $8 \%$ \\
\hline & total Respondents & $\mathbf{2 5}$ & $\mathbf{1 0 0}$ \\
\hline
\end{tabular}

Source: Personal (data processing)

Table 4 shows that the educational level of employees of Public Relations and Protocol Regional Secretariat Banjarbaru the Respondents in this study were 6 people $(24 \%)$ had high school/equivalent, 8 (23\%) education diploma, 9 (36\%) educated Bachelor and $2(8 \%)$ of graduate education.

\section{Descriptive Analysis Questionnaire Answers Respondents}

Recapitulation of respondents aimed to describe the research variables through the interpretation of the frequency distribution of respondents overall. This is seen in the number of respondents (people), as well as in the percentage figure of the variable item. The frequency for respondents to 
answer questions Extrinsic motivation variable (X1) and Intrinsic Motivation (X2) and Employee
Performance (Y) can be seen in Table 5 below:

Table-5: Item Variable Frequency Distribution Extrinsic motivation (X1) and Intrinsic motivation (X2) and Employee Performance (Y)

\begin{tabular}{|c|c|c|c|c|c|c|c|c|c|c|}
\hline \multicolumn{10}{|c|}{ Respondents answer } \\
\hline item & 1 (STS) & \multicolumn{2}{|c|}{2 (TS) } & \multicolumn{2}{|c|}{$3(\mathrm{~N})$} & \multicolumn{2}{c|}{$4(\mathrm{~S})$} & \multicolumn{2}{c|}{$5(\mathrm{SS})$} \\
\hline & $\mathrm{f}$ & & & $\%$ & & $\%$ & $\mathrm{f}$ & $\%$ & $\mathrm{f}$ & $\%$ \\
\hline $\mathrm{X} 1.1$ & 0 & 0 & & 0 & 3 & 12 & 13 & 52 & 9 & 36 \\
\hline $\mathrm{X} 1.2$ & 0 & 0 & 1 & 4 & 3 & 12 & 13 & 52 & 9 & 32 \\
\hline $\mathrm{X} 1.3$ & 1 & 4 & 2 & 8 & 4 & 16 & 10 & 40 & 8 & 32 \\
\hline $\mathrm{X} 1.4$ & 0 & 0 & 2 & 8 & 4 & 16 & 7 & 28 & 12 & 48 \\
\hline $\mathrm{X} 1.5$ & 0 & 0 & 1 & 4 & 3 & 12 & 16 & 64 & 5 & 20 \\
\hline $\mathrm{X} 2.1$ & 0 & 0 & 0 & 0 & 4 & 16 & 11 & 44 & 10 & 40 \\
\hline $\mathrm{X} 2.2$ & 0 & 0 & 1 & 4 & 6 & 24 & 8 & 32 & 10 & 40 \\
\hline $\mathrm{X} 2.3$ & 0 & 0 & 0 & 0 & 6 & 24 & 13 & 52 & 6 & 24 \\
\hline $\mathrm{X} 2.4$ & 0 & 0 & 0 & 0 & 3 & 12 & 11 & 44 & 11 & 44 \\
\hline X2.5 & 0 & 0 & 2 & 8 & 5 & 20 & 10 & 40 & 8 & 32 \\
\hline Y.1 & 0 & 0 & 0 & 0 & 4 & 16 & 16 & 64 & 5 & 20 \\
\hline Y.2 & 0 & 0 & 1 & 4 & 2 & 8 & 14 & 56 & 8 & 32 \\
\hline Y.3 & 0 & 0 & 0 & 0 & 2 & 8 & 10 & 40 & 13 & 52 \\
\hline Y.4 & 0 & 0 & 0 & 0 & 2 & 8 & 14 & 56 & 9 & 36 \\
\hline Y.5 & 0 & 0 & 0 & 0 & 2 & 8 & 9 & 36 & 14 & 56 \\
\hline
\end{tabular}

Based on Table 5 above, of the variables Extrinsic motivation (X1) on the item questions (X1.1) of 25 (twenty-five) employees of Public Relations and Protocol Regional Secretariat Banjarbaru predominant answer is as many as 13 people (52\%) responded agree, the item question (X1.2) is the most dominant answer as many as 13 people (52\%) answered agree, the item question (X1.3) is the most dominant answer as many as 10 people $(40 \%)$ answered agree, the item question (X1.4) is the most dominant answer as many as 12 people (48\%) strongly agreed and answered the question item $(\mathrm{x} 1.5)$ is the most dominant answer as many as 16 people $(54 \%)$ responded strongly agree

Intrinsic motivation variable (X2) on the item questions (X2.1) of 25 (twenty-five) employees of Public Relations and Protocol Regional Secretariat Banjarbaru predominant answer is as many as 11 people $(44 \%)$ answered agree, the item question (X2. 2) the most dominant answer is as many as 10 people (40\%) answered strongly disagree, question item (X2.3) is the most dominant answer as many as 13 people (52\%) agree answer question items (X2.4) the most dominant response is much 11 people $(44 \%)$ answered disagree and strongly disagree and question items (X2.5) is the most dominant answer as many as 10 people (40\%) responded to agree.
Of variable Employee Performance (Y) to the question item (Y.1) of 25 (twenty five) employees of Public Relations and Protocol Regional Secretariat Banjarbaru predominant answer is as many as 16 people (64\%) disagree, question item (Y. 2) the most dominant answer is as many as 14 people (56\%) answered agree, the item question (Y.3) is the most dominant answer as many as 13 people $(52 \%)$ answered agree, the item question (Y.4) predominant answer is as many as 14 (56\%) agreed to answer questions and items (Y.5) is the most dominant answer as many as 14 people (56\%) responded strongly agree.

\section{Validity and Reliability Test}

Item questions on the independent and dependent variables considered valid if it has a correlation value are greater than $r$ syarat, research instruments can be considered valid if the correlation coefficient> of 0.3 Sugiyono in Supriyanto and Machfudz [9] concluded that all items are valid questions. The reliability test was conducted to examine the extent to which the gauges reliable or trustworthy. In this study, the reliability value of an instrument is accepted if it has a Cronbach alpha of at least 0.6. Arikunto in Supriyanto and Machfudz [9], it can be concluded that all the items question is reliable (reliable or trustworthy). The results of the validity and reliability of the research instrument can be seen in Table 6 below: 
Table-6: Summary of Results of Validity and Reliability Research Instruments

\begin{tabular}{|c|c|c|c|c|c|}
\hline variables & item & $\mathbf{R}$ & Information & $\boldsymbol{\alpha}$ & Information \\
\hline \multirow{4}{*}{ Extrinsic Motivation } & $\mathrm{X} 1.1$ & 0.763 & valid & & \\
(X1) & $\mathrm{X} 1.2$ & .738 & valid & & \\
& $\mathrm{X} 1.3$ & 0.779 & valid & 0,765 & reliable \\
& $\mathrm{X} 1.4$ & .701 & valid & & \\
& $\mathrm{X} 1.5$ & 0.666 & valid & & \\
Intrinsic Motivation & $\mathrm{X} 2.1$ & 0,702 & valid & & \\
(X2) & $\mathrm{X} 2.2$ & 0.856 & valid & & \\
& $\mathrm{X} 2.3$ & .730 & valid & 0.847 & reliable \\
& $\mathrm{X} 2.4$ & .790 & valid & & \\
\hline \multirow{5}{*}{ Employee performance } & $\mathrm{X} 2.5$ & 0.858 & valid & & \\
(Y) & $\mathrm{Y} .1$ & 0.608 & valid & & \\
& $\mathrm{Y} .3$ & 0,645 & valid & & \\
& $\mathrm{Y} .4$ & .875 & valid & 0,692 & reliable \\
& $\mathrm{Y} .4$ & .528 & valid & & \\
\hline
\end{tabular}

Source: Personal (data processing)

From Table 6 above can be seen on the Validity of all items have questions correlation values> 0.3 it can be stated all items in this research question are valid. Based on the test results of all the instruments acceptable reliability for the Cronbach alpha> 0.6. it can be concluded that all the items question is reliable (reliable or trustworthy).

\section{Multiple Linear Regression}

As formulated the hypothesis interpreted as a formula or tentative conclusion regarding a study made to explain the study and also can guide or direct future research. Based on the issues raised, the research hypothesis:

1. Work Motivation consisting of Intrinsic Motivation Extrinsic motivation and simultaneously have a significant effect on employee performance of Public Relations and Protocol Banjarbaru Regional Secretariat.

2. Work Motivation consisting of Intrinsic Motivation Extrinsic motivation and partially significant effect on employee performance of Public Relations and Protocol Banjarbaru Regional Secretariat.

3. Variables the dominant influence on the performance of employees of Public Relations and Protocol Regional Secretariat Banjarbaru is Extrinsic motivation (X1)

Testing is done with a confidence level of $95 \%$ or 0.05 level of significance $(\mathrm{a}=0.05)$. To test the hypothesis then used multiple linear regression analysis. In this regression analysis test will be conducted simultaneously, partial and dominant, while recapitulation regression test results are as follows:

Table-7: Regression Test Results

\begin{tabular}{|c|c|c|c|c|}
\hline variables & $\begin{array}{l}\text { The regression } \\
\text { coefficient (bi) }\end{array}$ & $\mathbf{t}$ & beta & sig \\
\hline constants & 9.139 & & & \\
\hline Extrinsic motivation (X1) & 0,339 & 2.927 & 0.477 & 0,008 \\
\hline Intrinsic motivation (X2) & 0,260 & 2.286 & 0.372 & 0,032 \\
\hline \multicolumn{2}{|l|}{ Constant $=9.139$} & \multicolumn{3}{|c|}{$\mathrm{F}$ count $=11.041$} \\
\hline \multicolumn{2}{|l|}{ Multiple $\mathrm{R}=0.708$} & \multicolumn{3}{|c|}{ Sig $=0,032$} \\
\hline \multicolumn{2}{|l|}{$\mathrm{R}$ square $(\mathrm{R} 2)=0.501$} & & & \\
\hline
\end{tabular}

Source: Personal (data processing)

In Table 7 visits $R$ Square of 0.501 which means large variations across the independent variables on the contribution of the dependent variable is $50.1 \%$ while the remaining $49.9 \%$ is explained by other causes outside of the study. Based on the regression equation Table 7 as follows:

$$
\mathrm{Y}=1.746+0.339 \mathrm{X} 1+0,260 \mathrm{X} 2+\mathrm{ei}
$$

Based on these equations, showed that all independent variables have a positive regression coefficient. This means that the variables Extrinsic motivation (X1) and Intrinsic Motivation (X2) have a direct relationship or proportional to the dependent variable or employee performance $(\mathrm{Y})$. That is if the variable $\mathrm{X} 1$ and $\mathrm{X} 2$ increase then the dependent variable $\mathrm{Y}$ also increased, and if $\mathrm{X} 1$ and $\mathrm{X} 2$ have decreased, then the dependent variable $\mathrm{Y}$ will decline. 
a) The constant value of 1.746 means that if there is no independent variable, then the performance is there for 1,746 Employees

b) Value $\mathrm{X} 1=0,339$, means that if the variables Extrinsic motivation up one unit, it will increase employee performance by 0,339 .

c) Value X2 $=0.260$, Intrinsic Motivation means that if variable ride one unit, it will increase employee performance by 0,260 .

Interpretation of the constants $(1,746)$ measurements in this study in which the variables using a Likert scale of 1 to 5 it should not be interpreted that if the variables Extrinsic motivation (X1) and Intrinsic Motivation (X2) is zero, because these three variables may not be zero because the lowest Likert scale used is 1 and based on the calculation of SPSS version 21.0 of this research is the constant value of 9.136 and included in the category of very strong.

\section{Hypothesis testing \\ Hypothesis I: Test F Simultaneous}

This test is used to establish whether the independent variables jointly affect the dependent variable. In answer to a hypothesis that has been proposed at the beginning of the study, using the SPSS software analysis tool version 21:00. From the calculation results through SPSS determine Fhitung 11.041 [9], if the significance $<0.05$, it can be inferred independent variables significantly influence the dependent variable, based on the theory of the sig F count was $0.000<0.05$, so the first hypothesis which says that consisted of Work Motivation and Extrinsic Motivation Intrinsic Motivation simultaneously significant effect on employee performance of Public Relations and Protocol Regional Secretariat Banjarbaru be accepted or tested.

\section{Hypothesis II: Test $\mathbf{t}$ Partial}

Through this testing will be known whether the variables comprising Extrinsic motivation (X1) and Intrinsic Motivation (X2) effect partially on Work Performance (Y) In the Office of Religious Affairs Banjar Regency, that is by comparing the value of the probability of significance of variables with a probability of $5 \%(\alpha=0.05)$ when the significance probability value $<(\alpha=0.05)$ then there is a significant effect on the dependent variable, and vice versa, while the statistical calculation results can be seen in Table 5.9 below:

Table-8: Value t

\begin{tabular}{|l|c|c|c|c|}
\hline The independent variable & $\mathbf{t}$ & Sig. & Information & Significant or not significant \\
\hline Extrinsic motivation X1 & 2.927 & 0,008 & Sig $<0.005$ & Significant \\
\hline X2 Intrinsic Motivation & 2.286 & 0,032 & Sig $<0.005$ & Significant \\
\hline \multicolumn{7}{c}{ Source: Personal (data processing) }
\end{tabular}

According to the table, 8 visits Effects of the Extrinsic motivation variable (X1) to Labor Capacity (Y). It can be seen from Table 5.9 which has the significance probability value is $0.008<0.05$, so it can be concluded that Extrinsic motivation (X1) significant effect alone or partially on Performance (Y) Employees of Public Relations and Protocol Banjarbaru Regional Secretariat. Effect of Intrinsic Motivation variables (X2) on Work Performance (Y), Intrinsic Motivation (X2) significantly partially on Work Performance (Y). It can be seen from Table 5.9 in which the significance probability value is $0.032<0.05$, so it can be concluded that partial Intrinsic Motivation (X2) significant effect alone - alone or partially on Performance (Y) Employees of Public Relations and Protocol Banjarbaru Regional Secretariat. Similarly, the second hypothesis which says that consisted of Work Motivation and Extrinsic Motivation Intrinsic Motivation partially significant effect on employee performance of Public Relations and Protocol Regional Secretariat Banjarbaru be accepted or tested.

\section{Hypothesis III: Variables Most Influential}

On hypothesis The third states that motivation extrinsic (X1) is the most influential factor to Performance (Y) is true or proven, because the results showed the value of Beta (Beta Coefficient) Variable Motivation extrinsic (X2) of 0.477> value Beta (Beta
Coefficient) Intrinsic motivation variable (X1) which is only 0.372 .

Overall described how extrinsic and the intrinsic interplay of performance simultaneously. Motivation Extrinsic and Intrinsic Motivation significant effect simultaneously on Employee Performance of Public Relations and Protocol Regional Secretariat Banjarbaru, research findings are consistent with research that found Iriani [2] Intrinsic Motivation, Motivation Extrinsic, and Work Discipline Influence on Performance Officer at the Office of the District Education Office Sambas find the results of intrinsic motivation, extrinsic motivation, and work Discipline simultaneously and partially significant effect on employee performance.

Extrinsic motivation significant effect partially on Employee Performance of Public Relations and Protocol Regional Secretariat Banjarbaru, the findings of this study are consistent with research conducted Iriani [2]. Intrinsic Motivation, Motivation Extrinsic, and Work Discipline Influence on Performance Officer at the Office of Education Office of Sambas find the results of intrinsic motivation, extrinsic motivation, and work Discipline simultaneously and partially significant effect on employee performance. 
Based on the frequency response from survey respondents that the variables Extrinsic motivation dominant respondents answered agree. This relates to the Wisdom of the leadership of Public Relations and Protocol Banjarbaru Regional Secretariat in the administration of the employees has been good and given the ease. Supervision of Public Relations and Protocol leadership of the Regional Secretariat Banjarbaru so far has been quite good. The salary received by an employee of Public Relations and Protocol Regional Secretariat Banjarbaru is following the burden of life during this time. Personal Relationships /among employees in the Public Relations and Protocol Regional Secretariat Banjarbaru intertwined with harmonious and Working Conditions employees of Public Relations and Protocol Regional Secretariat Banjarbaru is conducive.

Intrinsic Motivation significant effect partially on Employee Performance of Public Relations and Protocol Regional Secretariat Banjarbaru this study are consistent with research Iriani [2]. Intrinsic Motivation, Motivation Extrinsic and Work Discipline Effect on Employee Performance in the Education Office of Sambas district who find the research results Motivation intrinsic, extrinsic motivation, and work Discipline simultaneously and partially significant effect on employee performance. Based on the frequency response from survey respondents that variable Intrinsic Motivation dominant respondents answered agree. It is concerning if the Chairman of Public Relations and Protocol Regional Secretariat Banjarbaru motivate employees got success in work. Leaders of Public Relations and Protocol Regional Secretariat Banjarbaru motivate employees got success in work.

Leaders of Public Relations and Protocol Regional Secretariat Banjarbaru provide recognition awards for employees who excel, All employees of Public Relations and Protocol Banjarbaru Regional Secretariat has been working following a preferred job. An employee of Public Relations and Protocol Regional Secretariat Banjarbaru have a high responsibility in the work and leadership of Public Relations and Protocol Regional Secretariat Banjarbaru provide career development to employees who work well. Extrinsic motivation is a variable that dominant influence on employee performance of Public Relations and Protocol Regional Secretariat Banjarbaru, new research findings are the findings because previous studies not analyzed to determine the variables the dominant influence on the performance [10].

\section{CONCLUSION}

Motivation morale boosts a person, so that maximum use of the capabilities and expertise to achieve the goals of an organization. Motivation is important because the motivation is expected that employees can work hard with sincerity and enthusiasm to achieve labor productivity as much as possible. Behavior and attitudes can be influenced and stimulated by the desire, fulfillment and purpose and satisfaction. Stimuli will be raised both from within and outside. This, in turn, creates a boosting activity. Motivation, as a conscious effort, affects a person's behavior that leads to the achievement of organizational goals. Variable Intrinsic Motivation Extrinsic motivation and significant effect on the performance of Public Relations and Protocol Officer Regional Secretariat Banjarbaru partially where the influence of Extrinsic motivation by $47.7 \%$ and the effect of Intrinsic Motivation of $37.2 \%$. The influence of these two variables and Intrinsic Motivation Extrinsic motivation, it simultaneously (together) amounted to a $50.1 \%$ impact on employee performance of Public Relations and Protocol Banjarbaru Regional Secretariat. The study states that the variables of the dominant influence on employee performance are Extrinsic Motivation and effect by 47 .

\section{REFERENCES}

1. Handayaningrat. (2012). Pengantar Ilmu Administrasi dan Manajemen. Jakarta: CV. Haji Masagung.

2. Terry. (2010). Prinsip-Prinsip Manajemen. Bandung: PT. Bumi Aksara.

3. Creswell, J. W. (2010). Research design: pendekatan kualitatif, kuantitatif, dan mixed. Yogyakarta: PT Pustaka Pelajar.

4. Sritua, A. (2005). Metodologi Penelitian Ekonomi. Jakarta: UI Press.

5. Natsir, M. (2006). Metode Penelitian. Jakarta: Ghalia Indonesia.

6. Siagian. (2012). Kiat Meningkatkan Produktivitas Kerja. Jakarta: Rineka Cipta.

7. Sugiyono. (2012). Metode Penelitian Kuantitatif, Kualitatif Dan $R \& D$. Bandung: Alfabeta.

8. Umar, H. (2005). Metode Penelitian Untuk Skripsi dan Tesis Bisnis. Jakarta: Raja Grafindo Persada.

9. Supriyanto, A. S., \& Machfudz, M. (2010). Metodologi Riset Manajemen Sumberdaya Manusia. Malang.

10. Rivai, V. (2011). Manajemen Sumber Daya Manusia untuk Perusahaan dari Teori ke Praktik. Jakarta: PT Raja Grafindo Persada. 